\title{
TOROIDAL ALFVÉN EIGENMODE INDUCED RIPPLE TRAPPING
}

\author{
BY
}

R.B. WHITE, E. FREDRICKSON, D. DARROW, ET AL.

\author{
MARCH 1995
}

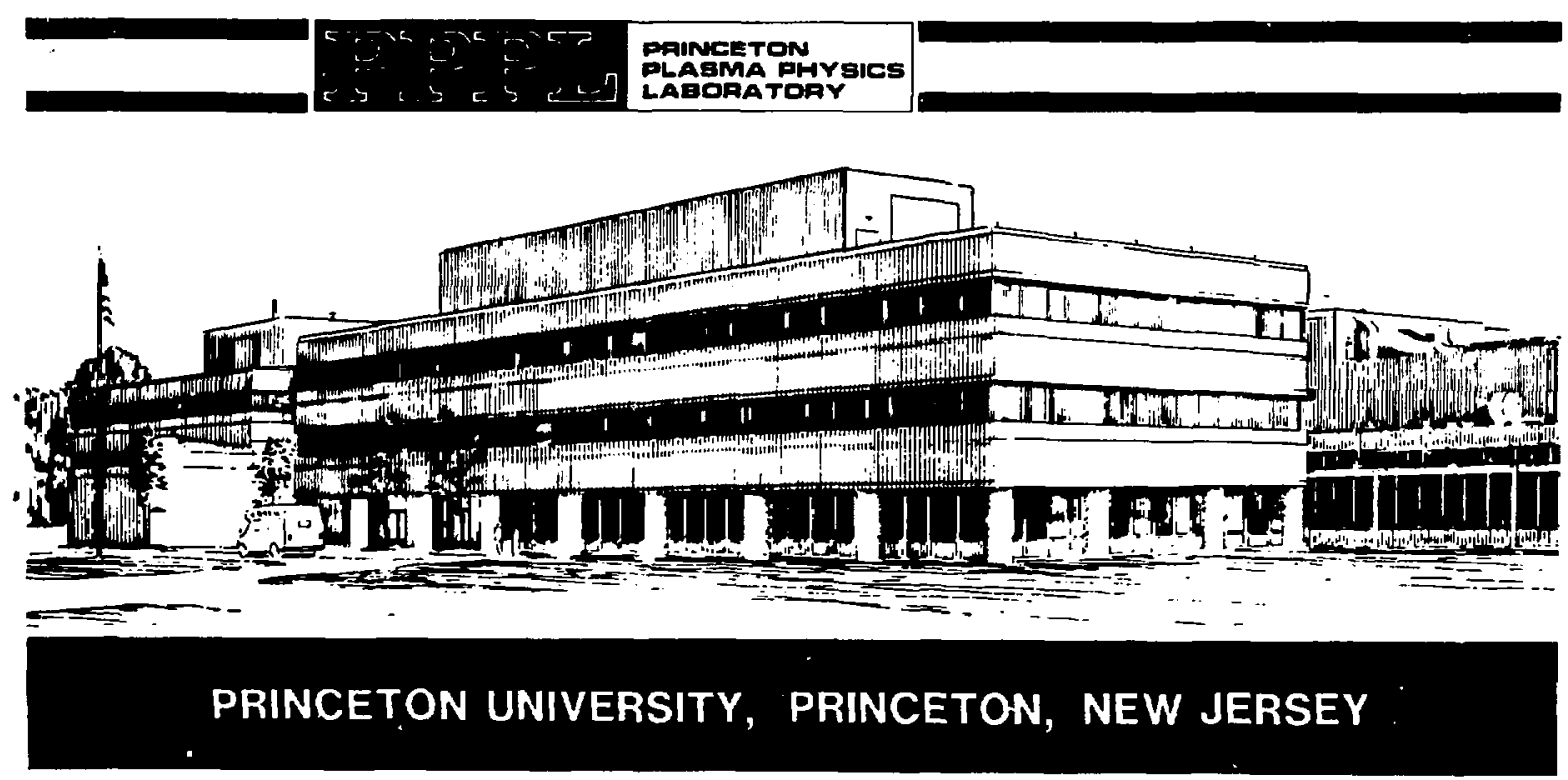




\section{NOTICE}

This report was prepared as an account of work sponsored by an agency of the United States Government. Neither the United States Government nor any agency thereof, nor any of their employees, makes any warranty, express or implied, or assumes any legal liability or responsibility for the accuracy, completeness, or usefulness of any information, apparatus, product, or process disclosed, or represents that its use would not infringe privately owned rights. Reference herein to any specific commercial produce, process, or service by trade name, trademark, manuf, sturer, or otherwise, does not necessarily constitute or imply its endorsement, recomm. ndation, or favoring . by the United States Government or any agency thereof. The views and opinions of authors expressed herein do not necessarily state or reflect those of the United States Government or any agency thereof.

\section{NOTICE}

This report has been reproduced from the best available copy. Available in paper copy and microfiche.

Number of pages in this report: 15

DOE and DOE contractors can obtain copies of this report from:

Office of Scientific and Technical Information

P.O. Box 62

Oak Ridge, TN 37831;

(615) 576-8401.

This report is publicly available from the:

National Technical Information Service

Department of Commerce

5285 Port Royal Road

Springfield, Virginia 22161

(703) $487-4650$ 


\title{
Toroidal Alfvén Eigenmode Induced Ripple Trapping
}

\author{
R. B. White, E. Fredrickson, D. Darrow, M. Zarnstorff, R. Wilson, S. Zweben, K. Hill, \\ Yang Chen, Guoyong Fu \\ Plasma Physics Laboratory, Princeton University, P.O.Box 451 , \\ Princeton, New Jersey 08540
}

\begin{abstract}
Toroidal Alfven Eigenmodes are shown to be capable of inducing ripple trapping of high energy particles in tokamaks, causing intense localized particle loss. The effect has been observed in TFTR.
\end{abstract}

PACS numbers: 52.35.Py, 52.35.Bj

Collective alpha-driven instabilities such as the toroidicity-induced Alfvén eigenmodes (TAE) are of concern for future tokamak devices since they can induce anomalous alpha losses. Previously discussed mechanisms of particle loss have consisted of induced transition from passing to direct-loss trapped orbits and radial diffusion produced by stochasticity in particle orbits caused by overlapping resonances ${ }^{1}$. In this work we point out a very effective loss process in devices possessing magnetic ripple wells. It differs from other forms of TAE induced loss in that the mechanism possesses no threshold mode amplitude. The effect has been observed in the Tokamak Fusion Test Reactor (TFTR), where particle fluxes intense enough to damage the vacuum wall were observed.

The process is very simply understood using a simple model for the magnetic field. Consider a trapped particle whose banana tip is in the vicinity of a ripple well. In guiding center approximation the particle energy is given by

$E=\frac{1}{2} m v_{\|}^{2}+\mu B$

MASTER 
Model the field as a large aspect ratio circular equilibrium modulated by toroidal ripple

$B=\frac{B_{0}(1+\delta \sin (N \phi))}{R}$

with $\mathrm{N}$ the number of toroidal field coils, $\delta$ the local ripple strength, and $R=R_{0}+r \cos (\theta)$ the major radius. To leading orders in gyro radius to system size a trapped particle moves periodically between the bounce points in poloidal angle $\theta$ and slowly precesses from the initial field line with the toroidal angle given by , $\phi=q \theta+\omega_{d} t$ with $\omega_{d}$ the toroidal precession rate. Energy conservation then reduces the problem to a particle moving in a one dimensional potential given by $\mu B(\theta)$. A ripple well exists at points where $d B / d \theta=0$ which requires

$\delta>\frac{r|\sin (\theta)|}{R q N}$

In TFTR the ripple magnitude is well represented by $\delta=\delta_{0} e^{\sqrt{\left(R-R_{r}\right)^{2}+b Z^{2}} / w}$ with $R_{r}=$ $223 \mathrm{~cm}, w=18.3 \mathrm{~cm}, \delta_{0}=1.4 \times 10^{-5}, Z=r \sin (\theta)$, and $b=1.1$. Consider a trapped particle whose banana tip is in the vicinity of a ripple well below the midplane (plasma current clockwise from above), i.e. the particle passes over a local well before bouncing. Ripple trapping occurs due to the fact that a particle is radially further outward after bouncing than before, due to the banana width. Field ripple increases strongly in this direction and thus the particle encounters larger ripple after bouncing, and may be trapped in the well. If this occurs it drifts vertically to the wall and is lost. Since the well location varies due to the toroidal precession, eventually all trapped particles on orbits with bounce points intercepting the ripple well domain will be lost. The presence of a time dependent magnetic perturbation such as the TAE mode produces additional modulation of the particle position which can greatly increase the phase space of particles capable of making the transition to a trapped state.

To demonstrate the mechanism we model the high energy particle distribution, equilibrium, and mode structure approximating those present in TFTR during the observation of this effect. The high energy particle distribution produced by heating was observed to cause destabilization of the TAE mode, in agreement with numerical analysis ${ }^{2}$. The toroidal 
mode number observed was $n=4$ and we include all important poloidal harmonics, i.e. $m=4-12$. The calculation of the eigenmode profile and spectral components has been studied analytically ${ }^{3}$ and numerically using the NOVA code ${ }^{4}$. The code results are used in this paper. In Fig.1 are shown the eigenfunctions obtained with NOVA. The mode frequency used was the experimentally observed TAE frequency of $188 \mathrm{kHz}$. However we find that the results are insensitive to the form of the eigenmodes used, as long as the mode amplitude is large in the ripple trapped domain. We used modes with $\delta B / B=2 \cdot 10^{-3}$ in the simulations. Comparison with the Mirnov coil measurements are not practical because of the different boundary conditions in the eigenvalue code (no vacuum region). The amplitude was set by comparison with the observed fractional loss in high energy tail energy. Total lost particle fluxes are not measured in the experiment, so cannot be compared directly.

Simulation is done using a Hamiltonian guiding center code ORBIT described previously. ${ }^{5,6}$

The equilibrium had a major radius $R=262 \mathrm{~cm}$, a minor radius $a=100 \mathrm{~cm}$, with a safety factor of $q=.8+3.2(r / a)^{2}$. For these parameters the domain where ripple wells exist is rather large, and is shown in Fig 2. Also shown is the reduction in the ripple well domain which would be produced by decreasing the TFTR ripple by a factor of 2 or 4 . The particle distribution is a model high energy Hydrogen minority tail ion distribution chosen to fit that produced during the experiment, given by

$F=e^{\left(E-\mu B_{\pi / 2}\right)^{2} / c} e^{-E / T} e^{-r^{2} / b^{2}}$

with $\mathrm{T}=370 \mathrm{keV}$, the width parameter $\mathrm{c}$ adjusted to give $75 \%$ trapped particles, $\mathrm{b}=33 \mathrm{~cm}$, and $B_{\pi / 2}$ the value of the field at $\mathrm{r}, \theta=\pi / 2$.

Two populations of lost particles were observed in the simulations, those with banana orbits intersecting the wall, having pitch $\lambda=v_{\|} / v \approx .5$ and impacting the wall just below the midplane, and the ripple trapped population, with $\lambda \approx 0$, intersecting the wall at a location determined by the existence of ripple wells and by the TAE amplitude. An example of a TAE induced ripple trapping event is shown in Fig. 3. In Figs 4, 5 are shown the lost particle 
distributions in $R$ and pitch, both with and without the presence of the TAE mode. The ripple trapped population peaks near $R=315 \mathrm{~cm}$ which, as seen in Fig. 2, corresponds to the smallest value of $\mathbf{R}$ at which the ripple trapped domain extends across the plasma vertically including the high density central domain. Without a TAE mode, since the simulations did not include a source of high energy particles, but rather a fixed initial distribution, the ripple trapped flux is of short duration. In the experimental situation, which included a continuous source of high energy particles, this would translate into a small total intensity. A TAE mode moves particles in phase space, and allows a much larger population of particles to become ripple trapped. The simulations show a more intense ripple trapped flux of much longer duration in the presence of the mode. There is no threshold amplitude for this process, the total flux being approximately lineas in the mode amplitude. Reduction of ripple by $1 / 2$ or $1 / 4$ would move this domain significantly outward, as shown in Fig. 2, with a large reduction in flux.

Details of the experiment confirming this process will be reported in a separate publication. Three different observations confirm the model sketched above. First, intense metallic influxes are observed in the plasma, predominantly of manganese. Second, thin stainless steel debris shields located at the bottom of the vacuum vessel at a major radius of $305 \mathrm{~cm}$ were melted. Third, strong fluctuations were measured in the expected TAE range during the experiments.

In conclusion, high energy particle loss consisting of ripple trapping induced by high frequency MHD perturbations has been modeled and observed in TFTR. The mode observed was a TAE mode destabilized by the high energy tail produced by ICRF heating, but any high frequency mode could produce similar results. Finally we point out that this loss mechanism is not effective for the alpha particle distribution in ITER because of the very small ripple well domain. 


\section{ACKNOWLEDGMENTS}

This work was supported by the U.S. Department of Energy under contract number DEAC02-76-CHO3073.

\section{DISCLAIMER}

This report was prepared as an account of work sponsored by an agency of the Uniter States Government. Neither the United States Government nor any agency thereof, nor any of their employees, makes any warranty, express or implied, or assumes any legal liability or responsibility for the accuracy, completeness, or usefulness of any information, apparatus, product, or process disclosed, or represents that its use would not infringe privately owned rights. Reference berein to any specific commercial product, process, or service by trade name, trademark, manufacturer, or otherwise does not necessarily constitute or imply its endorsement, recommentation, or favoring by the United States Government or any agency thereof. The views and opinions of authors expressed herein do not necessarily state or reflect those of the United States Government or any agency thereor. 


\section{REFERENCES}

1. D. J. Sigmar, C. T. Hsu, R. B. White, and C. Z. Cheng, Phys. Fluids B 4 (6), 1506 (1992).

2. C. Z. Cheng, Phys. Reports 211, 1 (1992).

3. C. Z. Cheng and M. S. Chance, Phys. Fluids 29, 3695 (1986).

4. C. Z. Cheng and M. S. Chance, J. Comput. Phys. 71, 124 (1987).

5. R. B. White and M. S. Chance, Phys. Fluids 27, 2455 (1984).

6. R. B. White, Phys. Fluids B 2, 845 (1990). 
Figure Captions

Fig. 1 TAE eigenmode as determined by NOVA-K for the TFTR shot 79459 , with $n=4$ and $m=4-12$. Only a few of the $m$ values used are shown.

Fig. 2 The ripple well domain in TFTR. Also shown are the resulting smaller domains if the ripple in TFTR were reduced by a factor of 2 or 4 .

Fig. 3 An example of TAE induced ripple trapping, using the parameters of shot 79459 .

Fig. 4 Simulation results shewn lost particle distribution in $R$ with (open) and without (black) the TAE mode.

Fig. 5 Simulation results shown lost particle distribution in pitch with (open) and without (black) the TAE mode. 


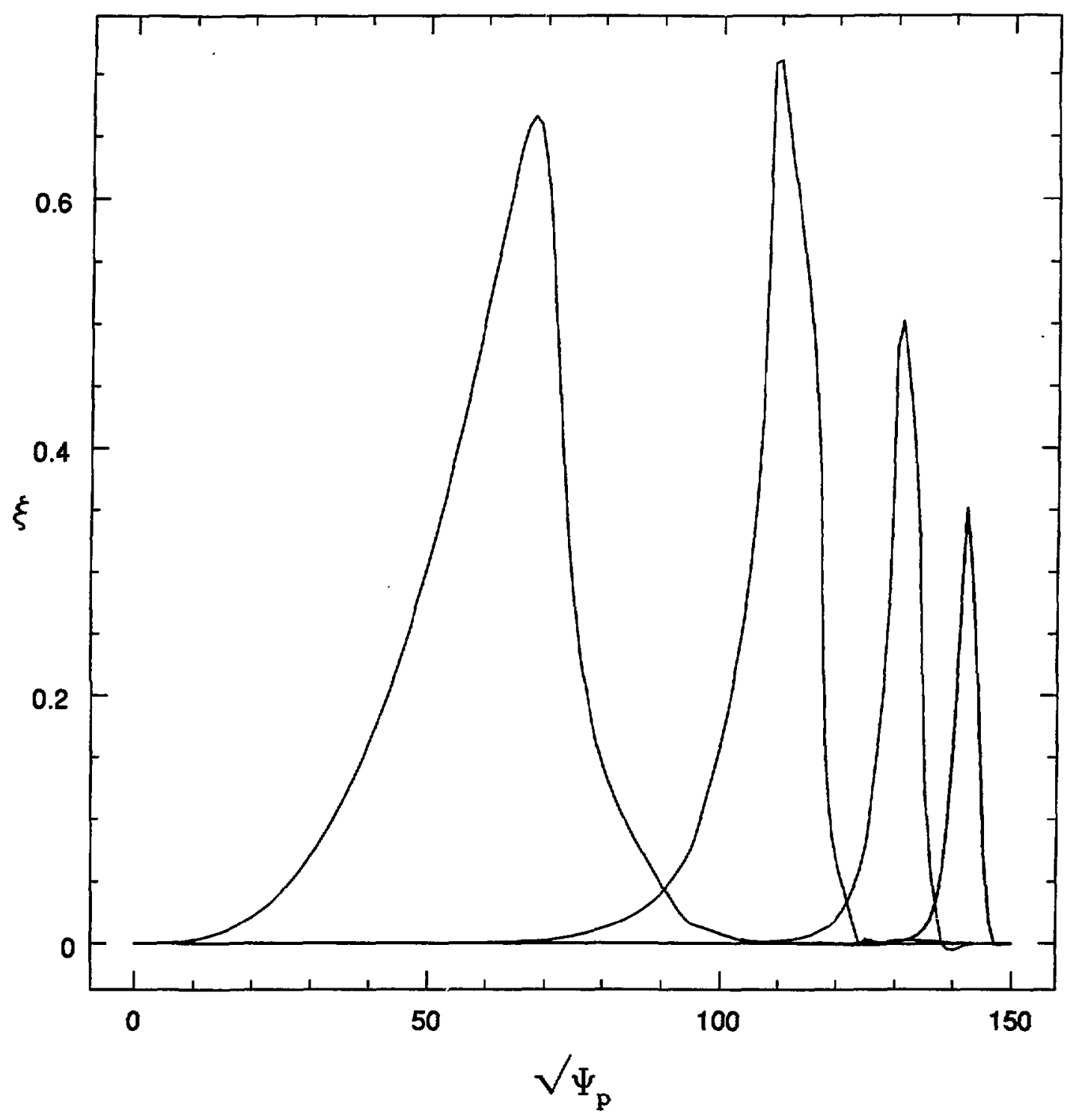

Fig. 1 


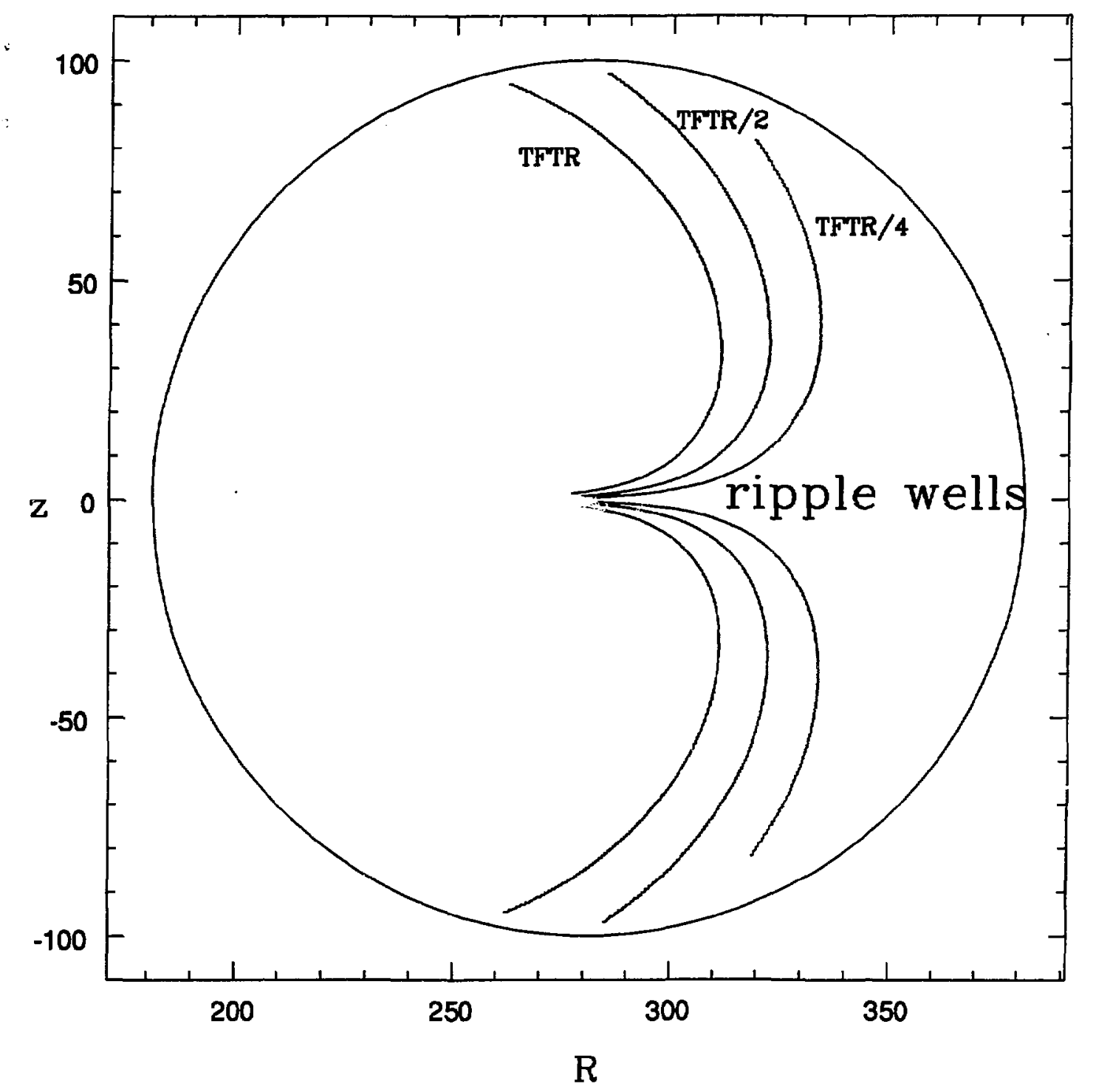

Fig. 2 


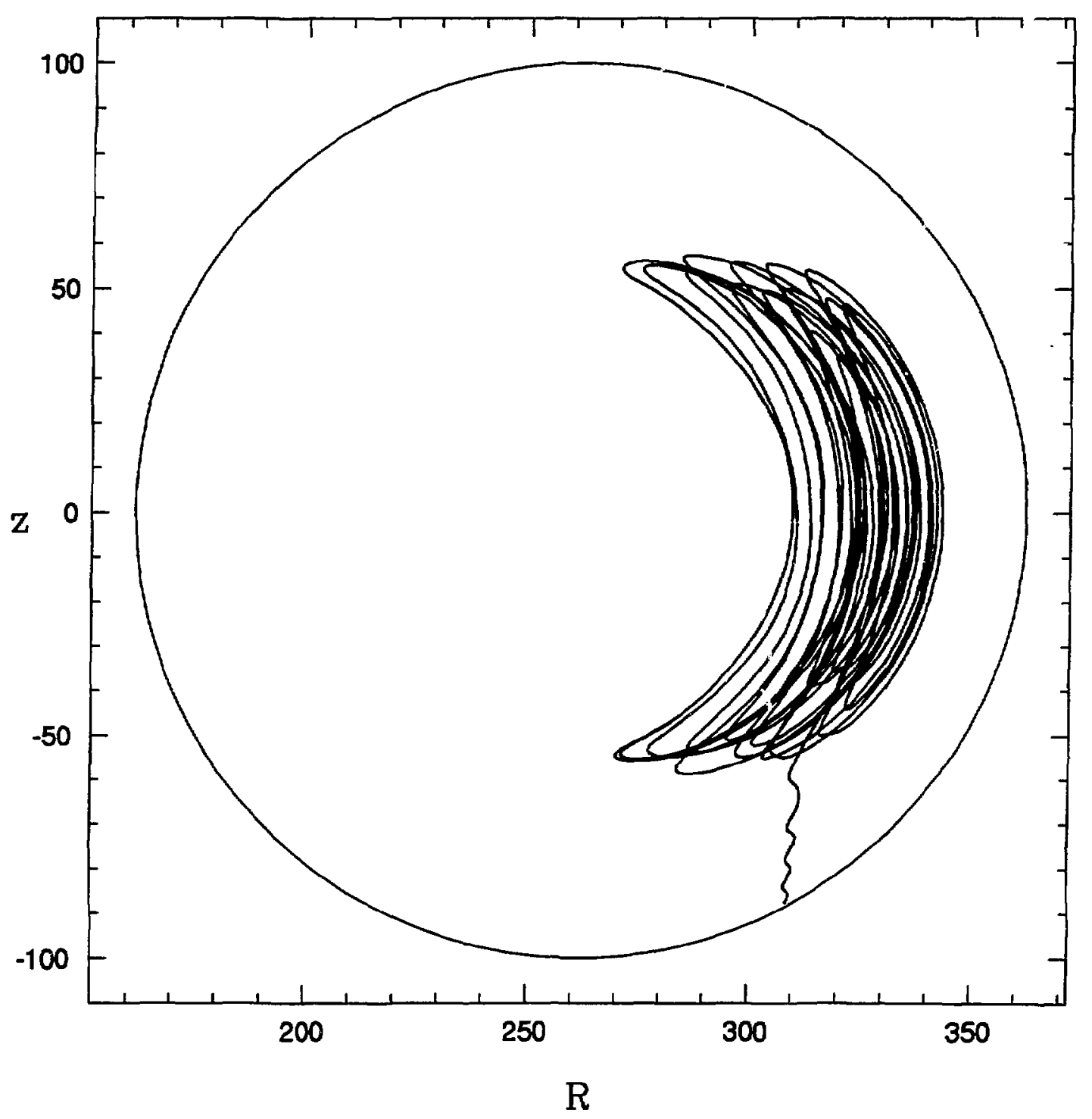

Fig. 3 


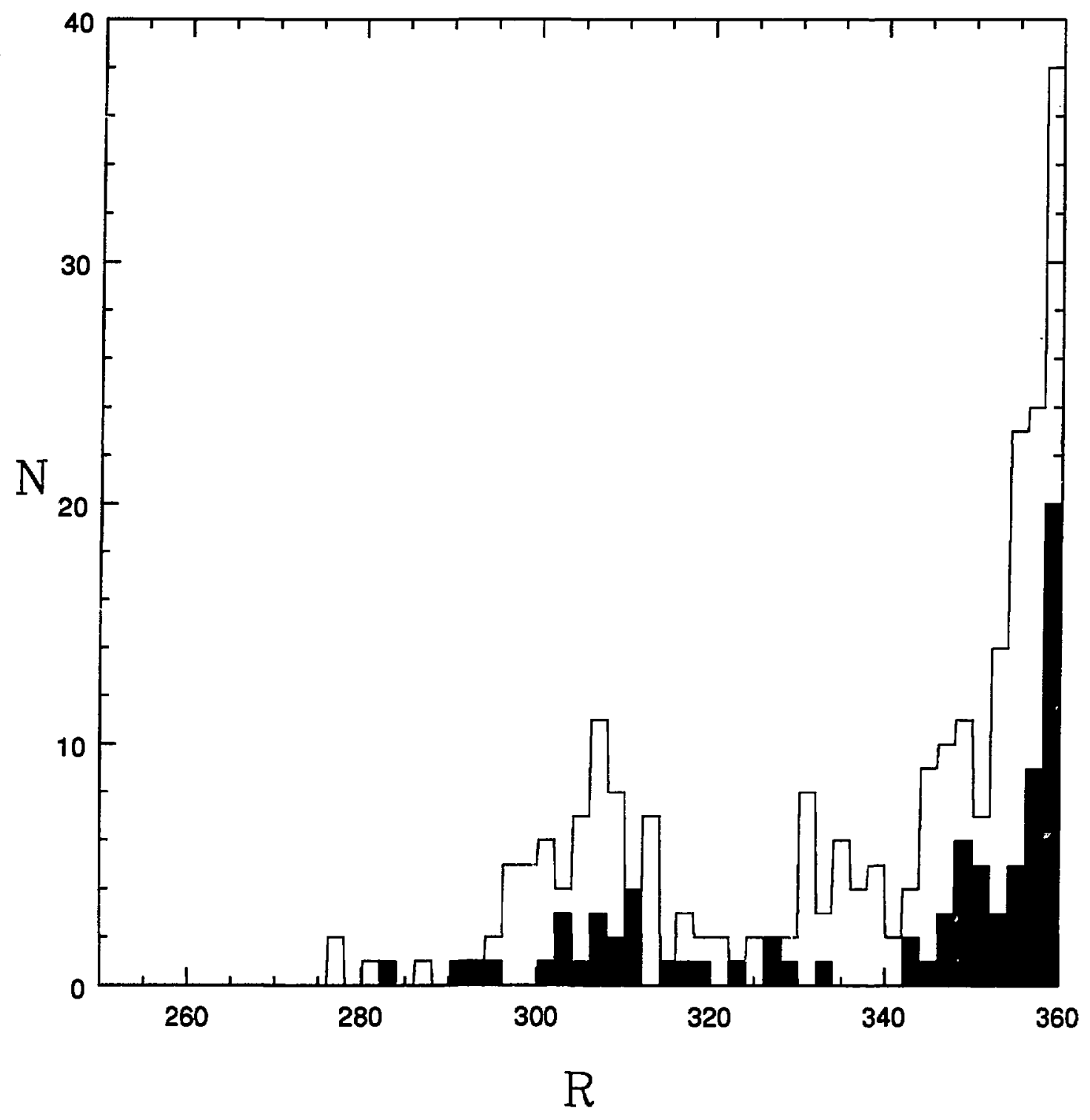

Fig. 4 


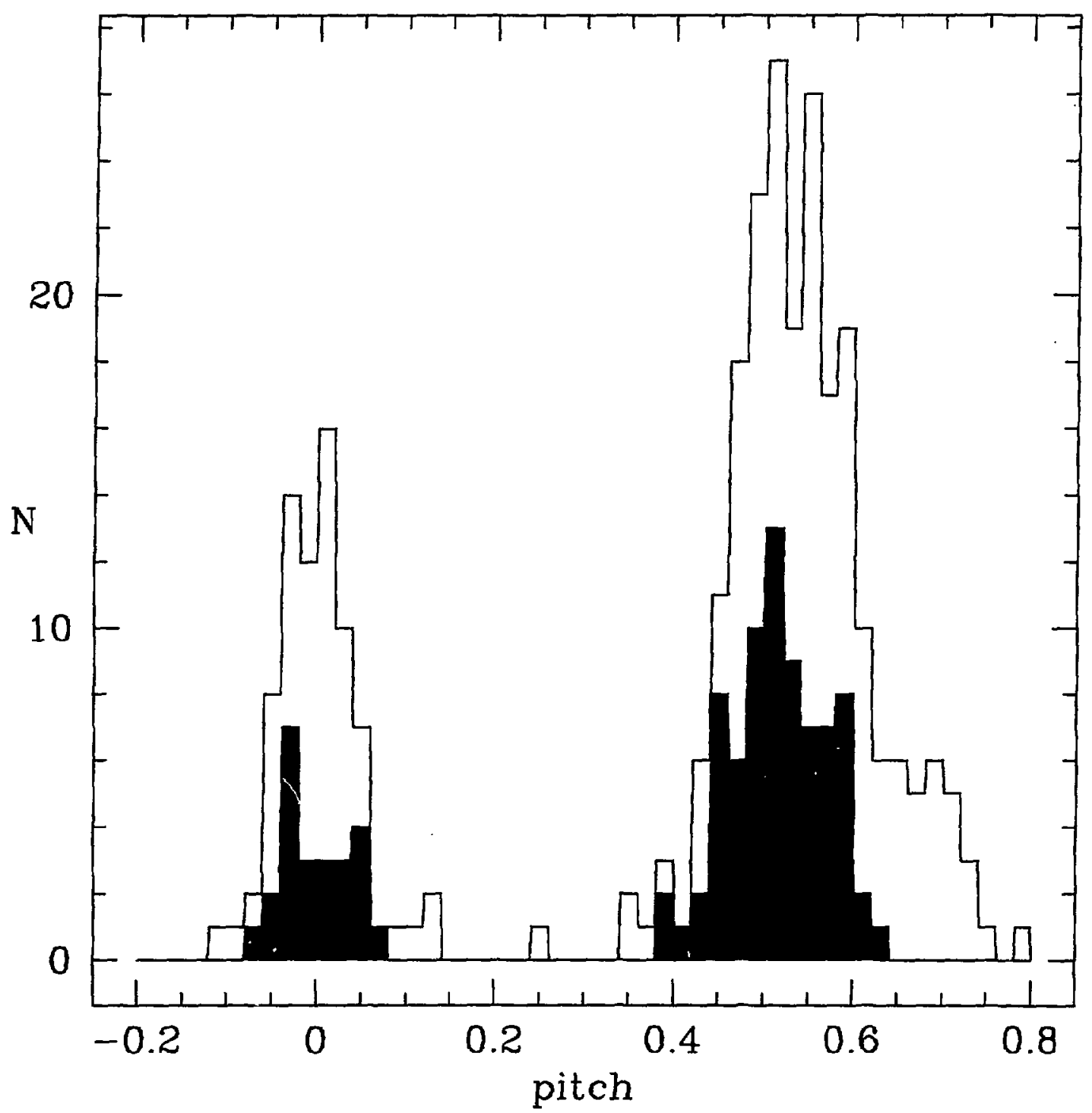

Fig. 5 
Dr. F. Paoloni, Univ. of Wollongong. AUSTRALIA

Prof. R.C. Cross, Univ. of Sydney, AUSTRALIA

Plasma Research Lab., Australien Nat. Univ., AUSTRALIA

Prof. I.R. Jones, Flinders Univ, AUSTRALIA

Prof. F. Cep, Inst. for Theoretical Physics, AUSTRIA

Prof. M. Heindler, Institut for Theorelische Physik, AUSTRIA

Prof. M. Gooseans, Astronomisch Instituut, BELGIUM

Ecole Royale Militaire, Leb. de Phy. Plasmas, BELGIUM

Commission-Eumpean, DG. Xll-Fusion Prog., BELGIUM

Prof. R. Bouciqué, Rijksuniversiteit Gent, BELGIUM

Dr. P.K. Sakanaka, Instihto Fisica, BRAZIL

Prof, Dr, I.C. Nascimento, Instituto Fisica, Seo Paulo, BRAZIL Instituto Nocional De Pesquisas Espaciais-INPE, BRAZIL

Documents Otfice, Alomic Energy of Canada Lid., CANADA

Ms. M. Morin, CCFMTokamak de Varennes, CANADA

Dr, M.P. Bachynski, MPB Technotogies, Inc., CANADA

Dr. H.M. Skarsgard, Univ. of Saskatchewan, CANADA

Prol. J. Teichmann, Univ. of Montreal, CANADA

Prol. S.R. Sreenivasan, Univ. of Calgary, CANADA

Prof. T.W. Johnston, INRS-Energie, CANADA

Dr. R. Bohon, Centre canadien de fusion magnétique, CANADA

Dr. C.F. James, Univ. of Albera, CANADA

Dr. P. LukAc, Komenskeho Universzita, CZECHO-SLOVAKIA

The Librarian, Culham Laboratory, ENGLAND

Library, R61, Rutherford Appleton Laboratory, ENGLAND

Mrs. S.A. Hutchinson, JET Library, ENGLAND

Dr. S.C. Sharma, Univ. of South Pacific, FIJI ISLANDS

P. Mähonen, Univ, of Helsinki, FINLAND

Prof. M.N. Bussac, Ecole Polytechnique, FRANCE

C. Mouttet, Lab. de Physique des Milieux lonisés, FRANCE

J. Radet, CEN/CADARACHE - Bat 506, FRANCE

Prof. E. Economou, Univ. of Crote, GREECE

Ms. C. Rinni, Univ. of loannina, GREECE

Preprint Library, Hunganian Academy of Sei., HUNGARY

Dr. B. DasGupta, Saha Inst. of Nuclear Physies, INDIA

Dr. P. Kaw, Inst. for Plasma Research, INDIA

Dr. P. Rosanau, lsrael Inst. of Technology, ISRAEL

Librerian, Intemational Center for Theo Physics, ITALY

Miss C. De Pab, Associazione EURATOM-ENEA ITALY

Dr. G. Grosse, Istitulo di Fisica ded Plasma, ITALY

Prof. G. Rostangni, Istitulo Gas Ionizzati Del Cnr, ITALY
Dr. H. Yamato. Toshiba Res a Devel Center, JAPAN

Prof. I. Kawakami, Hiroshima Univ., JAPAN

Prof. K. Nishikawa, Hiroshima Univ., JAPAN

Librarian, Naka Fusion Research Establishment, JAERI, JAPAN

Director, Japan Atomic Energy Research Inst, JAPAN

Prof. S. Isoh, Kyushu Univ., JAPAN

Research info. Ctr., National Instit. for Fusion Scienco, JAPAN

Prof. S. Tanaka, Kyoto Univ., JAPAN

Library, Kyoto Univ., JAPAN

Prof. N. Inoue, Univ. of Tokyo, JAPAN

Secretary, Plasma Section, Electrotectnical Lab., JAPAN

Dr. O. Mitarai, Kumamoto Inst. of Technology, JAPAN

Dr. G.S. Lee, Korea Basic Sci. Ctr., KOREA

J. Hyeon-Sook, Korea Atomic Energy Research Inst., KOAEA

D.I. Choi, The Korea Adv. Inst. of Sci. \& Tech., KOREP.

Prof. B.S. Liloy, Univ. of Waikato, NEW ZEALAND

Inst ol Physics, Chinese Acad Sci PEOPLE'S REP. OF CHINA

Library, Inst. of Plasma Physies. PEOPLE'S REP. OF CHINA

Tsinghua Univ. Library. PEOPLE'S REPUBLIC OF CHINA

Z. U, S.W. Inst Physics, PEOPLE'S REPUBLIC OF CHINA

Prot. J.A.C. Cabral, Instituto Superior Tecnico, PORTUGAL

Prot. M.A. Hellberg. Univ. of Natal, S. AFRICA

Prol. D.E. Kim, Pohang Inst. of Sci. \& Tech., SO. KOREA

Prol. C.I.E.M.A.T, Fusion Division Library, SPAIN

Dr. L. Stenflo, Univ. of UMEA, SWEDEN

Library, Royal Inst. of Technology, SWEDEN

Prof. H. Wilheimson, Chalmers Univ. of Tech., SWEDEN

Centre Phys. Des Plasmas, Ecole Polytech, SWITZERLAND

Bibliotheek, Inst. Voor Plasma-Fysica, THE NETHERLANDS

Asst. Prof. Dr. S. Cakir, Middle East Tech. Univ., TURKEY

Dr. V.A. Glukhikh,Sci. Fres. Inst. Electrophys.I Apparatus, USSR

Dr. D.D. Ayutor, Siberian Branch of Academy of Sci., USSR

Dr. G.A. Eliseev, I.V. Kurchatov Inst., USSR

Librarian, The Ukr.SSR Academy of Sciences, USSR

Dr. LM Kovrizhnykh, Inst. of General Physics, USSR

Kemforschungsanlage GmbH, Zentralbibliothek, W. GERMANY

Bibliothek, Inst. Für Plasmaforschung, W. GERMANY

Prof. K. Schindler, Authr-Universitát Bochum, W. GERMANY

Or. F. Wagner. (ASDEX), Max-Planck-Institut, W. GERMANY

Librarian, Max-Planck-Institut, W. GERMANY 